\section{UMĚLÁ INTELIGENCE V MEDICÍNĚ} Jan Hendl

\section{Anotace}

Termín umělá inteligence (Al) je aplikovatelný k široké škále postupů v medicíně, jako jsou robotika, medicínská diagnostika, medicínská statistika a humánní biologie. Al (a robotika) zcela mění prostředí medicíny a zdravotní péče. Vlna inovací transformuje proces klinického rozhodování, monitorování pacientů a péče, mění i prístup zdravotní péče o celou populaci (preventivní péče). Tyto změny také budou měnit role ošetřujícího personálu. Bude se měnit potřebné vzdělání a dovednosti. Al uvolní kliniky pro ostatní typy práce, což jim umožní více se věnovat smysluplné péči o pacienta.

Příspěvek upozorňuje na trendy a perspektivy uplatnění umělé inteligence $v$ medicíně.

\section{Klíčová slova}

umělá inteligence, robotika, definice, aplikace

\section{1 Úvod}

Umělá inteligence (AI) je termín, který znamená užití počítačů k modelování inteligentního chování s minimální intervencí člověka. Obecně se přijímá, že Al začala s aplikováním robotů $(3,5)$. Samotný termín „robot" byl využit Karlem Čapkem v roce 1921 v jeho hře R.U.R. (Rozumní Univerzální Roboti). V polovině 20. století Issac Asimov zvěčnil tento název ve sbírce krátkých vědecko-fantastických povídek. Humanoidní automat byl však poprvé zmíněn v Číně, kde Yan Shi (1023- 957 před Kristem) ukázal králi Mu z dynastie Zhou mechanickou figurínu velikosti člověka potaženou kůží, vlnou a s umělými orgány. V 12. století v zlatém věku muslimů polyhistor Al-Jazari vytvořil humanoidního robota, který dovedl hrát na činely. $V$ renesanci to byl Leonardo da Vinci, který vytvořil v roce 1495 podrobnou studii lidské anatomie, aby navrhl humanoidního robota - rytíre, který zvládal určité typické pohyby. Da Vinciho nákresy byly inspirací pro generace výzkumníků $v$ robotice, někteří z nich pracovali $\checkmark$ NASA.

V roce 1948 se William Gray Water stal slavným, když vyvinul autonomního robota, kterého nazval Machina Speculatrix. Jeho cílem bylo demonstrovat, jak funguje mozek. Pomocí spojení mezi relativně malým počtem "mozkových buněk“ prokázal, že i tak Ize realizovat dosti složité chování. John McCarthy použil v roce 1955 jako první označení Umělá inteligence (AI). U nás se věnuje umělé inteligenci kromě jiných také bratr Václava Havla, Ivan.

Dnes je Al považována za inženýrský obor, který implementuje nové koncepty a řešení, které jsou schopny řešit složité úkoly. Tím jak postupuje progres v rychlosti výpočtů, pamět’ové kapacitě a programování softwaru, počítače se mohou chovat jako lidé. Na Al má velký vliv kybernetika, jejímž zakladatelem byl Norbert Wiener. Jde o transdisciplinární prístup zacílený na ovládání systémů použitím technologie, která zkoumá regulaci systému, strukturu a omezení, mechanické, fyzikální, biologické a sociální.

Úzce spojená je Al s robotikou. Robotika je věda o robotech, jejich designu, výrobě a aplikacích. Robotika souvisí také s elektronikou, mechanikou a softwarem. $V$ príspěvku se zabýváme těmito tématy:

\section{Definice Al}

2. Historie AI

3. Definice exponenciálních technologií

4. Aplikace v medicíně

\section{Definice umělé inteligence}

Inteligence je základním kamenem lidské existence. Inteligence nám umožňuje porozumět např. větám. Mentální aktivita nás charakterizuje jako lidské bytosti. Na ní se podílí náš mozek ve spolupráci s různými částmi naší biologické výbavy (např. oči). Legg a Hutter shromáždili 70 definic „inteligence“, které zdůrazňují různé aspekty. Např. jde o adaptivitu nebo o optimalizační procesy, zdůrazňuje se schopnost dosáhnout určité cíle, učení a pružnost (2).

„Inteligence - podle jedné definice - je schopnost aktéra dosáhnout určité cíle v širším rozmezí okolí."

Stanfordská definice, která zahrnuje přirozenou inteligence lidí i umělou inteligenci zní:

„Inteligence je výpočetní část schopnosti dosáhnout cíle ve světě."

V této definici se odkazuje na interní procesy (výpočty), které slouží k dosažení externích cílů (schopnost dosáhnout cíle) $v$ rámci komplexního a dynamicky se měnícího okolí (svět).

Umělá inteligence je $v$ širším smyslu studium výpočetních operací, které umožňují vnímání, uvažování a jednání či automatizaci inteligentního chování. Přitom se studují biologické i umělé systémy. Al je definována také jako nehumánní inteligence měřená schopností replikovat lidské duševní schopnosti, jako rozeznávání obrazců, porozumění přirozenému jazyku, adaptivní učení ze zkušenosti a uvažování o ostatních.

Také existují přistupy, které nevidí prínos v napodobování člověka, ale místo toho se zaměřují na systémy, které simulují ideálně-racionální výkon. Podle tohoto přístupu Ize konkrétní aplikace zařadit do čtyř kategorií, které jsou dané dvěma binárními dimenzemi:

Dimenze 1: zdůrazňuje dosažení specifických procesů uvažování (U) nebo chování ( $\mathrm{CH})$.

Dimenze 2: měří úspěšnost ve vztahu k lidskému výkonu (L) nebo vzhledem k ideálnímu konceptu inteligence - obecně definována jak racionalita (R).

Typologie různých definic Al čtyřpolní tabulkou je zobrazena v tabulce 1.

Známý informatik a odborník v AI N. J. Nilsson (5) vyslovil definici Al ve tvaru: „Al je aktivita směřovaná $\mathrm{k}$ vytvoření strojů, které jsou inteligentní a inteligence je kvalita, která umožňuje entitě fungovat vhodně a s přehledem v jeho okolí."

\begin{tabular}{|l|l|l|}
\hline & Člověk jak vzor (L) & Racionalita jako vzor (R) \\
\hline $\begin{array}{l}\text { Inteligence je proces } \\
\text { myšlení (M) }\end{array}$ & $\begin{array}{l}\text { Systémy, které myslí jako člověk: Automatizace } \\
\text { aktivit, které asociujeme s lidským myšlením, } \\
\text { aktivity jako rozhodování, řešení problémů, učení }\end{array}$ & $\begin{array}{l}\text { Systémy, které „mysli“ racionálně. Studium } \\
\text { výpočetních procesů, které umožňují vnímat, uvažovat } \\
\text { a jednat. }\end{array}$ \\
\hline $\begin{array}{l}\text { Inteligence je cílově } \\
\text { orientované chování (CH) }\end{array}$ & $\begin{array}{l}\text { Systémy, které reagují jako člověk: Studium } \\
\text { vytváření strojů, které dělají věci, v kterých se } \\
\text { vyžaduje inteligence, pokud je vykonávají lidé. }\end{array}$ & $\begin{array}{l}\text { Systémy, které jednají racionálně: Odvětví informatiky, } \\
\text { které se týká automatizace inteligentního chování. }\end{array}$ \\
\hline
\end{tabular}




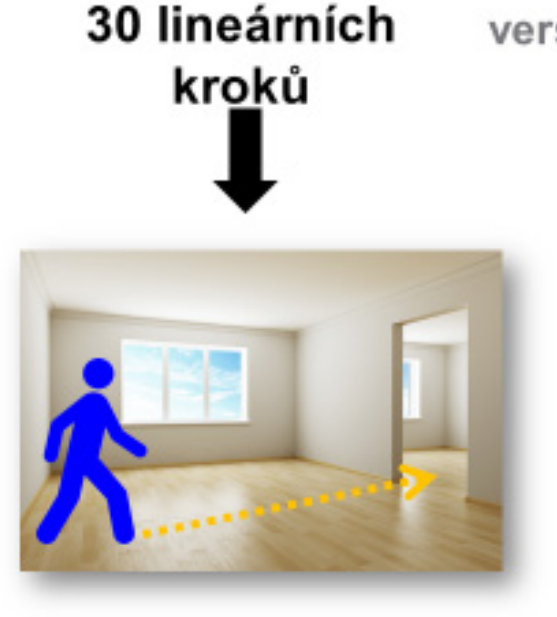

Kráčet přes místnost versus 30 exponenciálních

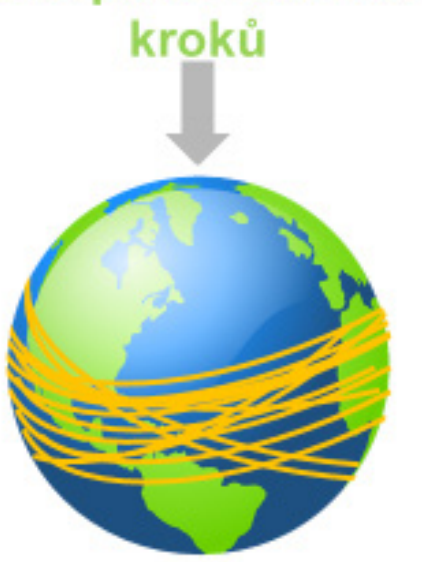

Obejit 26x kolem celé planety

JHend, FVS UK

Obr. 1 Jeden krok znamená při exponenciálním růstu mnohem více než v lineárním procesu.

\section{Dějiny rozvoje umělé inteligence}

$\checkmark$ protikladu k rozšiřenému mínění není Al zcela novou disciplínou. Mnoho základních konceptů je dosti starých (5). Na některé starší představy jsme upozornili v úvodu.

Oblast praktických aplikací se objevuje po druhé světové válce. Impulzy Al totiž dal vojenský výzkum. Například Alan Touring svými pracemi v oblasti kryptografie a výpočtu balistických křivek.

\section{První jaro 1956 - 1975}

Období prototypů systémů, které operují bezpečně v rámci dosti úzkých hranic umělého mikrosvěta. Jde o systémy na bázi formálního symbolického uvažování (jednoduché hry, 1) Historii Al Ize rozdělit na tyto etapy:

- 1) První jaro 1956 - 1975

- 2) První zima 1974-1980

- 3) Expertní systémy, druhé jaro 1980 - 1987

- 4) Druhá zima 1987 - 1993

- 5) Tréetí trvalejší jaro 1993 - 2011

- 6) Big data, exponenciální technologie a Al revoluce 2011 - dodnes

Postupně tyto etapy historického vývoje Al bliže charakterizujeme.

\section{První zima 1974-1980}

První vlna nadšení netrvala věčně. Bylo jasné, že rychlý vývoj se zpomalil. Al systémy byly velmi omezené. Bylo patrné, že kombinatorickou explozi nutných operací nelze zvládnout, což bylo demonstrováno vyčerpávajícím vyhledáváním, přístupem pokusu a chyby. Také se odhalila omezenost ve výkonu prvních modelů (perceptron). Snížily se finanční dotace.

Expertní systémy, druhé jaro 1980 - 1987

Druhá vlna se vyznačuje vstupem tzv. expertních systémů koncipovaných na základě pravidel, kdy je řešena úloha v rámci malého problému specifické znalosti. Tyto programy emulovaly rozhodovací procesy expertů. Expertní systémy se využívaly jako pomocník při dělání rozhodnutí. Byly navrženy algoritmy pro určení vícevrstvových neurálních sítí.

\section{Druhá zima 1987 - 1993}

Výzkum ale nepřinesl slibované výsledky. Mnoho Al specializovaných společností odpadlo. Malé výpočetní systémy převyšovaly drahé Al aplikace. ES neprokázaly velkou užitečnost.

Třetí trvalejší jaro 1993 - 2011

Po relativním zklamání došlo k opuštění snů a k príklonu k oblastem vyžadujících řešení specifických problémů. Jednalo se o „pragmatický obrat“. Znovu vznikl zájem o neurální sítě a genetické algoritmy. Vzniklé ES se vyznačovaly vlastností, že malé chyby vedly pouze $\mathrm{k}$ malému snížení výkonu. Pokrok také urychlilo působení Moorova zákonu, stále se zvyšovala výpočetní kapacita hardwaru, aplikace Al se začaly dostávat do širší veřejnosti. To symbolizuje vítězství IBM Deep Blue nad šachistou Garry Kasparovem, monitorování družic, robotika, řízení dopravy, a GOOGLE vyhledávací algoritmy, systémy pro rozpoznání řeči, autonomní dopravní prostředky. Zvyšovaly se finanční dotace (např. 7. programový rámec EU). Také teoretický výzkum - po překonání negativního dědictví spojeného s pojmem Al - vstupuje do svého tretího jara a stále kvete.

Big data, hluboké učení a Al revoluce 2011 - dodnes V současnosti probíhá třetí zrození Al. Tento úspěch je určen specifickými faktory jako: pokroky v neurovědách, a počítačové vědě, v aplikacích neurálních sítí při rozeznávání obrazců. Na rozvoj dále působí rostoucí výpočetní kapacita, rychlejší sítě, cloudová řešení, růst internetu věcí, Big dat, otevřené zdroje datových množin generovaných sociálními medii, rostoucí počet výzkumných skupin i v komerční sféře. Kumulativní vytváření znalostí. Snížení bariér v prístupu ke zdrojům. Kombinace hardware, finanční zdroje, otevřený vývoj a velké datové množiny. Vstupujeme do kognitivní éry, v které softwarové systémy se již tak neprogramují k vykonání určitých kroků, nýbrž se automaticky učí ve fázi tréninku, používání a zpětné vazby od uživatelů.

\section{Exponenciální technologie}

Definice: Exponenciální technologie označuje technologie, které se zdvojnásobí v síle a rychlosti každý rok, přičemž jejich náklady jsou každým rokem poloviční.

Dále uvedeme některé všeobecně známé příklady a představitele tohoto zaměření. 


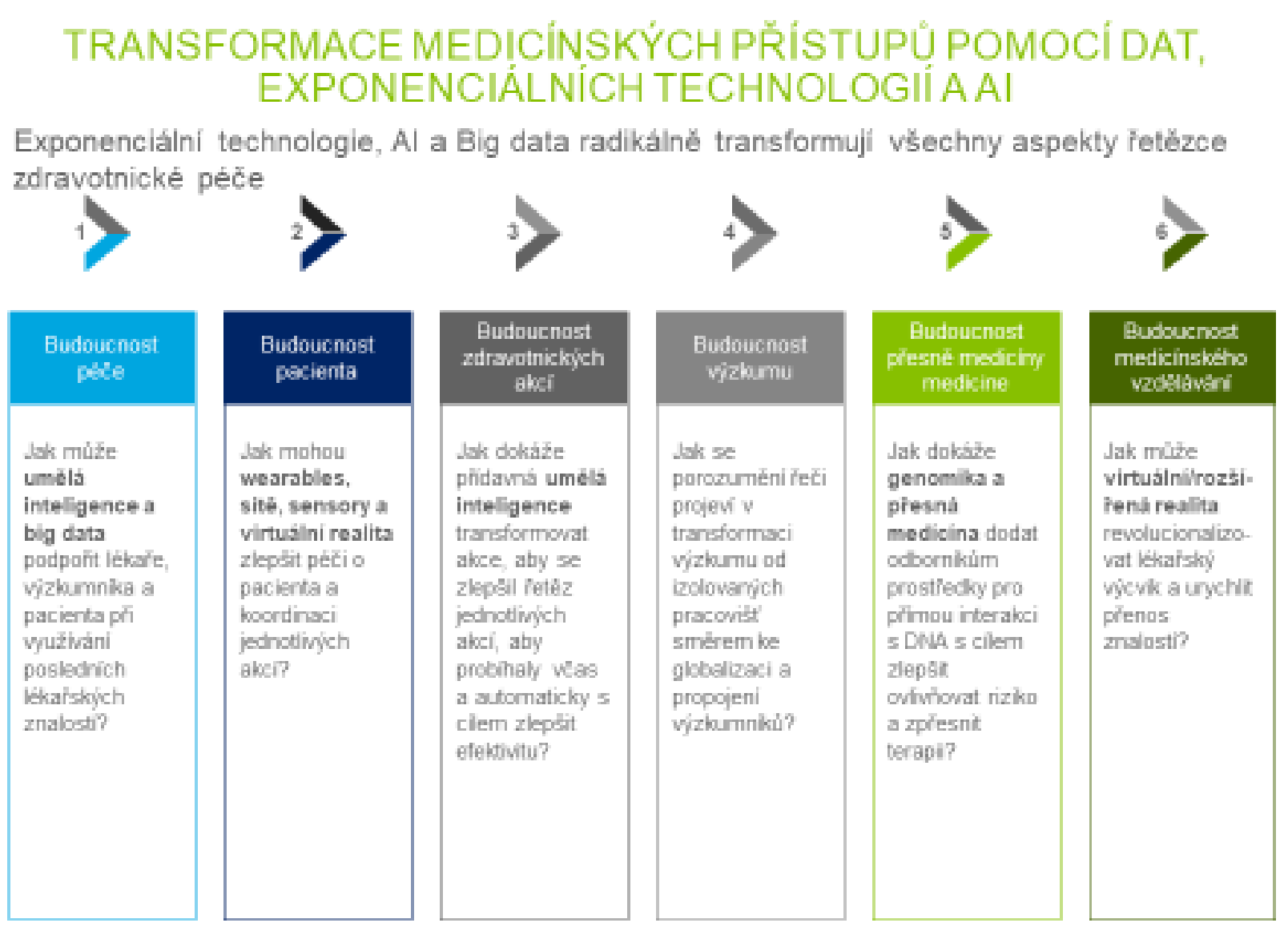

JHend, FVS UK

Obr. 2 Vliv technologií big data technik a Al na procesy v medicíně.

Př́klady exponenciálních technologií: Al, 3D tiskárny, syntetická biologie, sítě sensorů, drony.

Exponenciální podnikatel: Je nakloněn exponenciálním technologiím a opírá se o ně ve své činnosti (př.: Elon Musk, Richard Branson).

Cyklus růstu exponenciálních technologií se vyznačuje těmito vlastnostmi:

- Digitalizace: Technologie založené na informacích, datech.

- Klamání: Po prvních krocích se vytratí z horizontu, pak se znovu objeví,

- ale jsou mnohem dále (drony).

- Narušení: s jejich pokrokem nastávají rychlé změny v dané oblasti.

- Demonetizace: Jestliže technologie odstraní nutnost koupit něco jiného.

- Digitální fotografie odstranila opatřování filmu.

- Dematerializace: Fyzikální součástky jsou nahraženy digitalizací

- (pař.: encyklopedie -> wiki).

- Demokratizace: Snížení nákladů vede k jejich rozšíření mezi lidmi.

Exponenciální růst vede $\mathrm{k}$ nepřehlédnutelnému rozšíření technologie (viz obr. 1).

\section{Umělá inteligence $v$ medicíně}

Al v medicíně, což je těžiště tohoto přehledu, má dvě hlavní zaměěení: virtuální a fyzickou. Virtuální směr zahrnuje informa- tické přístupy k hlubšímu řízení informací využívané ke kontrole zdravotnických systémů, včetně elektronického zdravotního záznamu a aktivní pomoci lékařům v jejich rozhodování. Fyzický směr je reprezentován robotikou používanou při asistenci starším pacientům nebo přístupy k posílení operací. Tento směr také zahrnuje cílené nano-roboty a nové postupy pro dávkování léků $(3,6)$. Obrázek 2 charakterizuje ovlivnění medicíny pokrokem v exponenciálních technologií, Al a Big dat.

Al, exponenciální technologie a robotika musí řešit aktuální problémy medicíny:

1. Problémy v souvislosti s rostoucí četností chronických nemocí, zvyšování nákladů (stárnoucí populace), omezení zdrojů. Klasické informační systémy jsou spíše efektivní u kratších, vážných zdravotních episod.

2. Exploze dat. Například kožní specialista by se měl seznámit s 11000 novými články každý rok. Mnoho dat je nestrukturovaných, takže nejsou přístupné v normálních databázích.

3. Informační technologie umožňují pohyb směrem k řešení na bázi Al. V současnosti existují platformy pro péči v reálném čase. Budoucnost patři inteligentním řešením opírajících se o dostupnou evidenci a zaměřených na výsledek péče. Zlepšují individuální a rodinnou péči, predikci a preventivní medicínu.

4. Lepší technologie a zároveň její demokratizace (AI v android aplikacích). Využití pro proaktivní zvládání problémů se zdravím.

5. Ochota obecné veřejnosti k vyšší aktivitě, což je podporované pokroky v loT. Také ochota používat na Al založené pomůcky. 


\section{POUŽIVÁME VHLED POMOČ́ AI, BIG DAT AANALYTIKY KE ZLEPŠENI AKCI}

\section{Výhody pro pacienta}

1. Zjednodušuje jednotlivé každodenni aktivity: Placeni úțủ, nalezeni doktora v ckol, domluvit setkäni. rozpoznat beneffy teracie, zmena

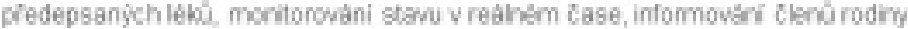
a leks'skich odbominos

2. Péce o chronicky nemocné pacienty: Monitorovàni hladin cukru, sledováni primu kalarii a jejch videje, pohybové aktivity, predtíni stižnasti

3. Péce kdekoliv: Pñspiva k porozumeri plánu pecte a propoustecich zprâ, pecte vdomścim prostjedi integrace bT

Zlepseni zdravotnického povèdomilkompetenci: Poskyouje persunalizavané, kortextualizavané tipy, daporuéeri a wysvétienti Proaktivné püsobi pri żepšavári zutavotriho stavu

5. Hraje roli informačniho agenta: D\&wa dohromady nüzns iformace o

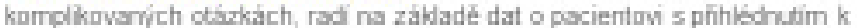
ckohosterm

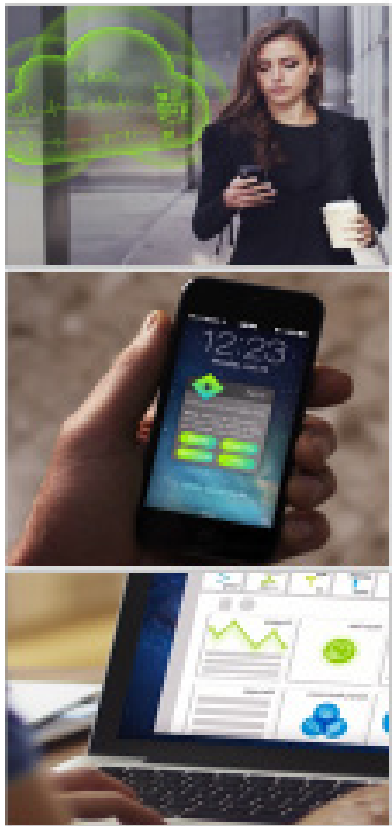

intelizent assistancs:

JHend, FVS UK

Obr. 3 Důležité oblasti změn v medicíně vlivem nových postupů Al, internetových sítí a robotiky.

Oblasti umělé inteligence a robotiky v medicíně

Jde o oblasti aplikací:

1) udržování zdraví, 2) včasná detekce poruch, 3) diagnostika, 4) rozhodování, 5) terapie, 6) paliativní péče, 7) výzkum, 8) výuka.

Stručně je charakterizujeme.

\section{1) Udržování zdraví}

Velký potenciál Al spočívá v pomoci lidem udržovat zdraví. Napřiklad inteligentní opasek upozorněním brání přejídání. Aplikace na základě Watson systému IBM s kognitivními schopnostmi. Zvyšuje proaktivní přístup k zachování zdraví i schopnosti ošetřujícího personálu. Potíže dělá množství dat.

\section{2) Včasná detekce poruch}

Zjištění rakoviny pomocí automatického zpracování mamogramů. Přenosné přístroje (wearables) umožňují zjistit první fáze srdečních onemocnění.

\section{3) Diagnostika}

$80 \%$ dat nelze analyzovat $v$ běžné databázi, protože nejsou v strukturované podobě. Aplikace IBM Watson dokáže uchovávat a využívat informace $z$ časopisů a nových knih. GOOGLE DeepMind Health odporuje spolupráci klinika, výzkumníka a pacienta při řešení zdravotních problémů.

\section{4) Rozhodování}

Zlepšení péče vyžaduje spojení analýzy dat s vhodným rozhodnutím. Simulace systémů pomocí modelování umožňuje sledovat vývoj fyziologických procesů v lidském těle. Simulace pomáhají farmaceutům, poskytovatelům péče, pacientům, výzkumníkům porozumět tomu, jak různá rozhodnutí ovlivňují zdraví.

\section{5) Terapie}

Kromě screeningu stávajících záznamů Al umožňuje úplnější přistup pro péči o nemocného $s$ danou diagnosou. Pomáhá sestavovat plán péče a pomáhá pacientovi s udržováním nastaveného léčebného programu. Například se uplatňují metody vizuálního rozpoznávání obličejů k identifikaci pocitů pacienta.

\section{6) Paliativní péče}

Roboty s pomocí Al pomáhají při péči o pacienty na konci jejich života. Pacienti tak zůstávají déle samostatní, pomáhá se jim $v$ denních úkolech a medikaci. Redukuje se tak potřeba kvalifikovaného personálu. Dokonce je možná konverzace mezi pacientem a humanoidem.

\section{7) Výzkum}

Cesta od výzkumu nové terapie až po akutní aplikaci u pacienta je dlouhá. Výzkum nových léků je novější aplikací Al. Ta může pomoci tuto dobu velmi zkrátit. Al pomáhá také při syntéze informací v odborné literatuře.

\section{8) Výuka}

Al umožňuje pomocí naturalistické simulace zlepšovat výuku zdravotnického personálu. Student může využít systémy s komponentami rozpoznávání řeči a s př́stupem k velkým databázím znalostí k zodpovězení odborných otázek. Navíc se systémy průběžné přizpůsobují znalostem studenta.

Změny vlivem nových technologií a postupů charakterizuje obrázek 3.

\section{Závěr}

Al (Artificial Intelligence) - umělá inteligence je popisovaná jako věda a inženýrství sestavování inteligentních strojů. Al 
se zrodila po druhé světové válce. Termín Al je aplikovatelný k široké škále postupů v medicíně, jako jsou robotika, medicínská diagnostika, medicínská statistika a humánní biologie - včetně všech různých "omics". Společenské a etické aspekty těchto aplikací vyžadují další reflexi, prokázání medicínské užitečnosti, ekonomické hodnoty a rozvoj interdisciplinárních strategií pro jejich širší aplikaci.

Al (a robotika) zcela mění prostředí medicíny a zdravotní péče. VIna inovací transformuje proces klinického rozhodování, monitorování pacientů a péče, mění i přístup zdravotní péče o celou populaci (preventivní péče). Tyto změny také budou měnit role ošetřujícího personálu. Bude se měnit potřebné vzdělání a dovednosti. Al uvolní kliniky pro ostatní typy práce, což jim umožní více se věnovat smysluplné péči o pacienta $(1,3,6)$.

\section{Literatura:}

[1.] KARŠULÍNOVÁ, V. (2014) Využití umělé inteligence v lékařství. Brno: Masarykova univerzita, Filozofická fakulta. (nepublikováno)

[2.] LEGG, S., HUTTER, M. (2007) A Collection of Definitions of Intelligence. [Cs], June 25. http://arxiv.org/abs/0706.3639.

[3.] HAMET, P., TREMBLAY, J. (2017) Artificial intelligence in medicine. Metabolism. Apr;69S:S36-S40. DOI: 10.1016/j.metabolism. 2017.01.011

[4.] HAVEL, I., M. (1992) Artificial Intelligence and Connectionism. In: Advanced Topics in Al (Mařík, Štěpánková, Trappl, editoři), Lecture Notes in Artificial Intelligence, Springer-Verlag 1992, s. 25-41.

[5.] NILSSON, N., J. (2010) The Quest for Artificial Intelligence: A History of Ideas and Achievements. Cambridge; New York: Cambridge University Press.

[6.] PWC (2017) What doctor? Why Al and robotics will define New Health. (staženo 2017: www.pwc.com)

\section{Kontakt:}

\section{Prof. Jan Hendl}

FSV UK - katedra sociologie

U Kř́iže 8 a 10

15800 Praha 5 - Jinonice

e-mail:jan.hendl@fsv.cuni.cz 